\title{
Comparison of two volumes for sciatic perineural injection using $1 \%$ methylene blue in rabbit cadavers
}

[Comparação de dois volumes para injeção perineural no nervo isquiático utilizando azul de metileno $1 \%$ em cadáveres de coelhos]

\author{
D.R. Jané ${ }^{1(\mathbb{D})}$, B.S. Gusmão ${ }^{(\mathbb{D})}$, B.B. Oliveira ${ }^{1(\mathbb{D})}$, L.P. Custódio ${ }^{1(\mathbb{D})}$, N.P. Reis Filho ${ }^{(\mathbb{D})}$, \\ T.A. Trein $^{3}$, B.P. Floriano ${ }^{2 *}(\mathbb{D})$ \\ ${ }^{1}$ Undergraduate, Centro Universitário das Faculdades Integradas de Ourinhos, Ourinhos, SP, Brasil \\ ${ }^{2}$ Centro Universitário das Faculdades Integradas de Ourinhos, Ourinhos, SP, Brasil \\ ${ }^{3}$ Practitioner, Porto Alegre, RS, Brasil
}

\begin{abstract}
The purpose of this study was to assess the efficacy of a blind technique for sciatic and femoral nerve block in rabbit cadavers by evaluating the spread of $1 \%$ methylene blue at two different volumes. Nine recently euthanized rabbits weighing $2.5 \pm 0.3 \mathrm{~kg}$ were used. The sciatic $(\mathrm{SN})$ and femoral $(\mathrm{FN})$ nerves of each limb were randomly assigned for injection with $1 \%$ methylene blue at $0.2 \mathrm{~mL} / \mathrm{kg}(\mathrm{G} 0.2)$ or $0.3 \mathrm{~mL} / \mathrm{kg}(\mathrm{G} 0.3)$. Nerves were dissected and measured for depth and extension of staining $(\mathrm{cm})$. Mean comparisons were performed using paired t test. The relation between volume and nerve staining $\geq 2 \mathrm{~cm}$ was assessed using chi-square test. The mean depth of SN was $1.9 \pm 0.2$ and $1.6 \pm 0.3 \mathrm{~cm}$ and staining $1.9 \pm 1.4$ and $2.0 \pm 1.2 \mathrm{~cm}$, respectively in G0.2 and G0.3. No relation was found between depth and dye spread and there was no association between nerve staining $\geq 2.0 \mathrm{~cm}$ and volume of solution. The FN failed to be stained in all subjects. In conclusion, SN injection can be successfully performed without guidance in rabbits. The lower volume $(0.2 \mathrm{~mL} / \mathrm{kg})$ is recommended to avoid systemic toxicity.
\end{abstract}

Keywords: laboratory animal, peripheral nerves, local anesthesia, nerve blocks, lagomorph, regional anesthesia

\section{RESUMO}

O objetivo deste estudo foi avaliar a eficácia de uma técnica para bloqueio às cegas dos nervos isquiático e femoral em cadáveres de coelhos, por meio da avaliação da dispersão de azul de metileno $1 \%$ em dois volumes distintos. Nove coelhos recém-eutanasiados, com peso $2,5 \pm 0,3 \mathrm{~kg}$, foram utilizados. Os nervos isquiático (NI) $e$ femoral (NF) de cada membro foram aleatoriamente designados para injeção com azul de metileno $1 \%$ a $0,2 \mathrm{~mL} / \mathrm{kg}(\mathrm{G} 0,2)$ ou $0,3 \mathrm{~mL} / \mathrm{kg}(G 0,3)$. Em seguida, foram dissecados e mensurados em relação à sua profundidade e extensão corada $(\mathrm{cm})$. As médias foram comparadas por meio de teste t pareado. A relação entre volume e extensão corada $\geq 2 \mathrm{~cm}$ foi avaliada utilizando-se teste de qui-quadrado. A profundidade média do NI

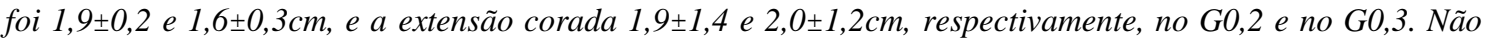
houve relação entre a profundidade e a extensão corada ou entre a extensão corada $\geq 2,0 \mathrm{~cm}$ e o volume de solução. Não foi observada coloração do NF em nenhum cadáver. Concluiu-se que a injeção do NI pode ser realizada com sucesso sem auxílio de tecnologias em coelhos. O menor volume $(0,2 \mathrm{~mL} / \mathrm{kg})$ é recomendado para evitar toxicidade sistêmica.

Palavras-chave: animais de laboratório, nervos periféricos, anestesia local, bloqueios neurais, lagomorfo, anestesia regional

\section{INTRODUCTION}

The number of exotic animals that have become companion animals has increased due to the interest for smaller and quieter pets, which also require less maintenance and space compared to dogs and cats. Many studies address small mammal anesthesia, although most are related to laboratory and experimental procedures (Heard, 2004). Lagomorph anesthesia is thus gaining attention as these species become more present in the small animal clinical care practice. Local anesthesia can be beneficial in addition to general anesthesia by reducing dose requirements, 
thereby minimizing adverse effects related to central and cardiorespiratory depression (Mosing et al., 2010). In addition, perineural blocks provide trans- and postoperative analgesia both for surgery and short outpatient procedures, providing greater comfort and safety for patients (Cervantes, 2011).

Few authors describe the use of local anesthesia in rabbits, including intra- and periconal block (Najman et al., 2015; Silva et al., 2015), subarachnoid injection (Belmonte et al., 2013), infraorbital, mentual, maxillary, mandibular, palatine block for dental procedures, as well as intratesticular block, epidural anesthesia (Lichtenberger and Ko, 2007) and brachial plexus block (Fonseca et al., 2015). Sciatic and femoral nerve blocks have not yet been described for rabbits in vivo. One study described the use of a peripheral nerve stimulator for sciatic nerve staining in rabbit cadavers with low volumes of solution (Sung, 2004). However, the authors did not intend to assess nerve staining, but rather to measure the distance between the needle tip and the nerve, which is completely different from the purpose of this study.

The sciatic nerve supplies the hamstring muscles, which comprise the biceps femoris, semitendinosus and semimembranosus, as well as the hip joint. At the medial aspect of the thigh, the sciatic nerve divides into tibial and common fibular nerves. The common fibular nerves supply the abductor cruralis caudalis muscle before giving rise to the superficial and deep fibular nerves. These nerves extend distally to the tarsal flexors and digit extensors at the dorsal aspect of the foot. The sciatic nerve also originates the tibial nerve, which divides into medial and lateral plantar nerves to supply the plantar aspect of the foot. The skin of the first and second digit is supplied by the saphenous nerve, a branch of the femoral nerve (Budras et al., 2012). Few studies report the use of peripheral nerve location and ultrasound guidance for sciatic nerve block in dogs (Shilo et al., 2010; Costa-Farré et al., 2011; Echeverry et al., 2012).

However, guided techniques are not always available in the clinical scenario, which is the predominant reality in most countries. Therefore, studies addressing the adequate volume of anesthetic solution for blind techniques can provide useful information to many physicians in the current scenario. The objective of this study was to assess the efficacy of a blind technique for sciatic and femoral nerve block in rabbits by evaluating the spread of $1 \%$ methylene blue at two different volumes in rabbit cadavers.

\section{MATERIAL AND METHODS}

Nine recently euthanized young albino rabbits weighing $2.5 \pm 0.3 \mathrm{~kg}$ were used for sciatic and femoral nerve injection. Animals were euthanized as part of another study in Centro Universitário das Faculdades Integradas de Ourinhos, which was approved by the Animal Usage Ethics Committee (protocol No. 018677/14). Euthanasia was humanely performed using an intravenous overdose of $2.5 \%$ sodium thiopental to achieve deep general anesthesia and apnea, followed by a bolus of $19.1 \%$ potassium chloride at $5 \mathrm{~mL}$. Injections and dissections were initiated after confirmation of death through absence of a heartbeat for at least 5 minutes following potassium chloride injection.

Two different volumes of $1 \%$ methylene blue solution (hydrated methylene blue, Neon Comercial, São Paulo State, Brazil) were compared on each hindlimb of the same cadaver, comprising two experimental groups: 0.2 and $0.3 \mathrm{~mL} / \mathrm{kg}$ (G0.2 and G0.3, respectively). Volumes were determined according to previous studies in dogs, which range from 0.1 to $0.3 \mathrm{~mL} / \mathrm{kg}$ using ultrasound guidance (Echeverry et al., 2010; Evangelista et al., 2017; Trein et al., 2017). For the purpose of performing a blind technique, higher volumes were selected for this study. Each hindlimb was randomly assigned to receive one of the volumes of solution using the random number function at Microsoft Excel.

The technique for perineural injection was performed according to Campoy et al., (2010). Cadavers were positioned in lateral recumbency with the limb to be injected uppermost and in natural extension. For the sciatic nerve, a $22 \mathrm{G}$ hypodermic needle (hypodermic needle Descarpack, Biotecmed, São Paulo State, Brazil) was inserted between the semimembranosus and semitendinosus muscles and advanced to a $2.3 \mathrm{~cm}$ depth according to a previous anatomical study in feline cadavers by the same authors. For the femoral nerve, the leg was abducted at 90 degrees and the needle was advanced through the skin proximal to the stifle from the sartorius muscle 
$1.5 \mathrm{~cm}$ to the inguinal area at the middle third of the thigh. The solution was injected over 10 seconds by the same person, who was unaware of the experimental group for each hindlimb. For this purpose, the syringe was coated with aluminum foil to prevent the anesthetist from knowing the volume of solution. The contralateral hindlimb was then injected using the same technique.

Dissection for assessment of nerve staining was performed immediately following injections. The skin at the lateral and medial side of each thigh was clipped. To expose the sciatic nerve, a skin incision was performed from the trochanter major of the femur to the stifle and reflected to each side, according to Echeverry et al. (2010). The biceps femoris muscle was dissected and sectioned at its middle third, to expose the underlying sciatic nerve. The femoral nerve was exposed through a three-incision technique. Two transverse incisions were performed, one at the midline of the inguinal abdomen and one at the stifle joint. A third incision was made connecting the lines and the skin was reflected cranially and caudally. The femoral nerve was found within the femoral triangle, next to the femoral artery and vein, after careful removal of fat tissue. Two measurements were performed on each cadaver: the depth of each nerve with regard to the puncture site; and the dye spread, both in centimeters using a digital

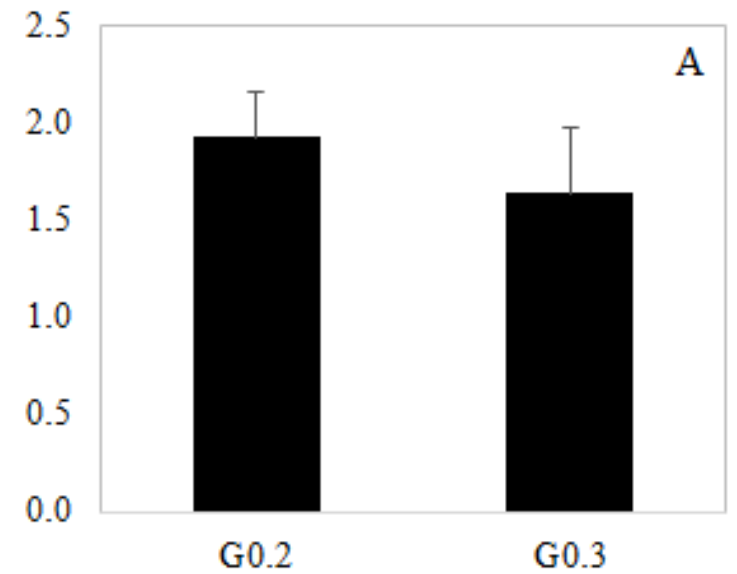

pachymeter (digital pachymeter Lee Tools, São Paulo State, Brazil). Data were initially tested for normality using the Shapiro-Wilk test. Mean comparisons were done using a paired t test. A Pearson correlation test was used to assess the possible correlation between the depth of the nerves and the extension of dye spread. The relation between volume of solution and dye spread $\geq 2 \mathrm{~cm}$ (Campoy et al., 2010) was assessed through a chi-square test. Differences were considered statistically significant when $\mathrm{p}<0.05$. All statistical analyses were performed using GraphPad Prism 6.

\section{RESULTS}

The mean depth of the sciatic nerve from the puncture site in the subjects of this study was $1.9 \pm 0.2$ and $1.6 \pm 0.3 \mathrm{~cm}$ and the spread of $1 \%$ methylene blue was $1.9 \pm 1.4$ and $2.0 \pm 1.2 \mathrm{~cm}$, respectively in G0.2 and G0.3 (Figure 1). The depth of the femoral nerve was $1.5 \pm 0.3 \mathrm{~cm}$ in both groups. The femoral nerve failed to be stained in all subjects. No correlation was found between sciatic nerve depth and dye spread in any group and there was no statistically significant association between the $2-\mathrm{cm}$ extension of the dye and the volume of solution in each group $(\mathrm{P}>0.05)$.

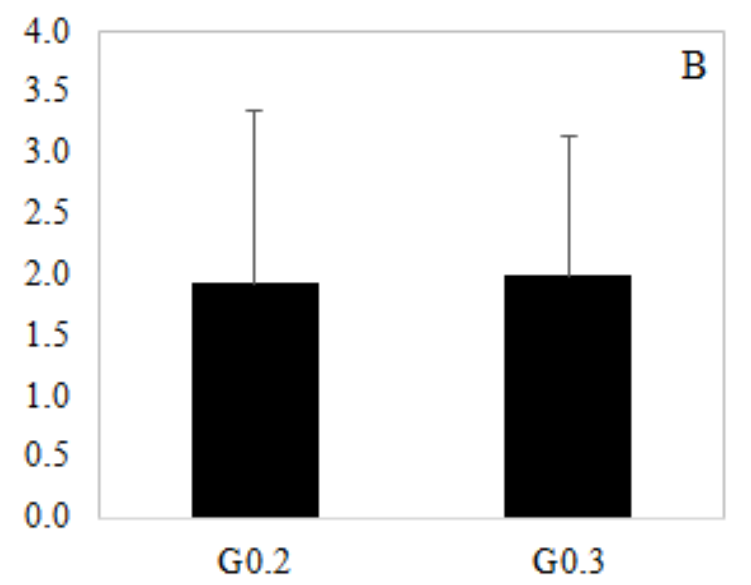

Figure 1. Mean and standard deviation of sciatic nerve depth (A) and $1 \%$ methylene blue spread (B) following perineural injection with $0.2(\mathrm{G} 0.2)$ or $0.3(\mathrm{G} 0.3) \mathrm{mL} / \mathrm{kg}$ in rabbit cadavers (Oryctolagus cunigulus $)$. Means do not differ according to paired t test $(\mathrm{P}>0.05)$.

\section{DISCUSSION}

The aim of the study was to demonstrate the effectiveness of sciatic and femoral block using a blind technique, which proved to be unsuccessful for the femoral nerve. Nevertheless, the results on the sciatic nerve present an interesting perspective for local anesthesia of rabbits, since the 
innervation of the foot is predominantly supplied by branches of this nerve. The foot is innervated at its dorsal aspect by common digital dorsal branches of the superficial fibular nerve and dorsal metatarsal branches of the deep peroneal nerve. The plantar surface is supplied by the common digital plantar branches of the medial plantar nerve and plantar metatarsal branches of lateral plantar nerve, which arise from the tibial nerve. Both the fibular and the tibial nerve are branches of the sciatic nerve (Budras et al., 2012).

Sciatic nerve anesthesia can be useful for many procedures on the foot, including wound management, which is common in rabbits due to pododermatitis (De Lahunta and Glass, 2014). The saphenous nerve contributes to the innervation of the first and second digits (Budras et al., 2012), however, its contribution usually ends at the middle third of the metatarsus (Lopez et al., 2012). In addition, one study in humans showed that saphenous nerve block does not provide useful analgesia during bunion surgery (Papeschi, 2018), therefore enhancing the predominance of sciatic innervation in the foot.

In rabbits, pododermatitis or bumblefoot is a common occurrence involving the plantar metatarsus and phalanxes. Bumblefoot is usually a result of obesity or keeping animals in graded cages and can be diagnosed based on typical wound characteristics. The clinical appearance can be ulcerative, granulomatous and chronic, and usually requires extensive management with wound cleansing, debridement and multiple dressings over days (Hess, 2004; Lahunta and Glass, 2014). For this purpose, sciatic blockade can be useful to avoid the need of general anesthesia and provide adequate analgesia during wound management. A few cases of rabbit pododermatitis can be associated with osteomyelitis, which warrants the need for additional diagnostic tests (Flecknell and Thomas, 2015). Patients could benefit from sciatic nerve block during positioning for radiographic imaging. Also, the study of Lopez et al. (2012) demonstrated that the involvement of bone tissue on the foot requires only sciatic nerve block for proper analgesia.

The lack of correlation between nerve depth and dye spread suggests that, regardless of anatomical variations on nerve depth, blind sciatic block is easily performed with success in rabbits. To date, no studies addressing blind perineural blocks for the hindlimbs of rabbits have been found, which renders this an interesting finding for laboratory animal anesthesia. With regard to volume of solution, this study showed lack of difference between groups, as well as a lack of association between each volume and the ideal extension of nerve staining ( $\geq 2 \mathrm{~cm}$ ) (Campoy et al., 2010) and, therefore, sciatic nerve block can be performed in rabbits using $0.2 \mathrm{~mL} / \mathrm{kg}$ of local anesthetics.

The toxic dose of local anesthetics commonly used in veterinary medicine is $10 \mathrm{mg} / \mathrm{kg}$ for lidocaine and $2 \mathrm{mg} / \mathrm{kg}$ for bupivacaine in rabbits (Flecknell and Thomas, 2015). The use of a larger volume $(0.3 \mathrm{~mL} / \mathrm{kg})$ for bilateral sciatic block would result in toxicity, which would not be the case with the lower volume $(0.2 \mathrm{~mL} / \mathrm{kg})$ used in this study. As a result, our findings allow sciatic nerve block to be performed bilaterally with safety in rabbits. Hindlimb analgesia can also be achieved by epidural anesthesia. However, epidural administration requires practice and is associated with more complications, such as accidental venous puncture (Harshavardhana and Gurudatta, 2015). In addition, the sciatic nerve is not accompanied by great vessels, as commonly seen with other important nerves in domestic animals (Budras et al., 2012). Sciatic nerve block is therefore safer and easier to perform compared to epidural anesthesia and can be an interesting alternative for practitioners.

The main limitation of this study was the lack of effective staining of the femoral nerve. The association between femoral and sciatic nerve block (Trein et al., 2017) would be interesting to allow more proximal interventions. The stifle is predominantly supplied by the saphenous nerve, a branch from the femoral nerve (Budras et al., 2012). This study was performed as part of a larger study involving femoral and sciatic nerve block in cats. The rabbit cadavers were acquired from a parallel study and were briefly used to assess whether the technique used in feline cadavers would suffice for the other species. Injections were performed in all cadavers prior to nerve dissection, and thus the anesthetist responsible for performing the injections applied the same techniques previously practiced on feline cadavers.

The anatomical differences at the femoral triangle of lagomorphs and felines showed that the needle 
should be directed deeper for perineural injection at the level of the femoral nerve in rabbits (Jané et al., 2018). This is the reason why, in this study, femoral injections failed to correctly stain the femoral nerve of rabbit cadavers. However, other studies with proper training on lagomorphs might produce better results with the femoral nerve. The results of this study are limited to distal procedures that cannot include the stifle.

\section{ACKNOWLEDGEMENTS}

Supported by the São Paulo Research Foundation (FAPESP No. 2017/17880-4).

\section{CONCLUSIONS}

In conclusion, sciatic nerve block can be successfully performed without technological guidance in rabbits using either volume of solution in this study. The lower volume $(0.2 \mathrm{~mL} / \mathrm{kg})$ is therefore recommended in order to avoid systemic toxicity related to local anesthetic doses. Guided techniques or proper anatomical training might be more appropriate for femoral nerve block in rabbits. This study is the first to address the adequate volume of solution for blind sciatic block in this species and its findings pose interesting perspectives for anesthesia of rabbits with common diseases of the foot.

\section{REFERENCES}

BELMONTE, E.A.; NUNES, N.; LOPES, P.C.F. et al. Cardiovascular variables in rabbits anesthetized with isoflurane and subarachnoid anesthesia with levobupivacaine or lidocaine. Rev. Port. Cienc. Vet., v.110, p.134-139, 2013.

BUDRAS, K.D; MCCARTHY, P.H.; HOROWITZ, A. Anatomy of the dog. 5.ed. Barueri: Manole, 2012. 224p.

CAMPOY, L.; BEZUIDENHOUT, A.J.; GLEED, R.D. et al. Ultrasound-guided aproach for axillary brachial plexus femoral nerve, and sciatic nerve blocks in dogs. Vet. Anaesth. Analg., v.37, p.144-153, 2010.

CERVANTES, S. Tecnicas de anestesia locoregional en la clínica felina. Clin. Vet. Pequenos Anim., v.31, p.5-15, 2011.
COSTA-FARRÉ, C.; BLANCH, X.S.; CRUZ, J.I. et al. Ultrasound guidance for the performance of sciatic and saphenous nerve blocks in dogs. Vet. J., p.221-224, 2011.

DE LAHUNTA, A.; GLASS, E. Veterinary neuroanatomy and clinical neurology. 3.ed. St Louis: Saunders, 2014. 540p.

ECHEVERRY, D.F.; GIL, F.; LAREDO, F. et al. Ultrasound-guided block of the sciatic and femoral nerves in dogs: a descriptive study. Vet. J., v.186, p.210-215, 2010.

ECHEVERRY, D.F.; LAREDO, F.G.; GIL, F. et al. Ultrasound-guided 'two-in-one' femoral and obturator nerve block in the dog: an anatomical study. Vet. Anaesth. Analg., v.39, p.611-617, 2012.

EVANGELISTA, M.C.; LASALLE, J.; CHEVRIER, C. et al. Distribution of bupivacaine hydrochloride after sciatic and femoral nerve blocks in cats: a magnetic resonance imaging study. Res. Vet. Sci., v.115, p.61-65, 2017.

FLECKNELL, P.A.; THOMAS, A.A. Comparative anesthesia and analgesia of laboratory animals. In: GRIMM, K.A.; LAMONT, L.A.; TRANQUILLI, W.J. et al. (Eds.) Veterinary anesthesia and analgesia: the fifth edition of Lumb and Jones. 5.ed. Ames: Wiley Blackwell, 2015. p.754-763.

FONSECA, C.; SERVER, A.; ESTEVES, M. et al. An ultrasound-guided technique for axillary brachial plexus nerve block in rabbits. Lab. Anim., v.44, p.179-184, 2015.

HARSHAVARDHANA, H.S.; GURUDATTA, C.L. Seizures following accidental intravascular injection of ropivacaine through epidural catheter. Indian J. Anaesth., v.59, p.125-125, 2015.

HEARD, D.J. Anesthesia, analgesia and sedation of small mammals. In: QUESENBERRY, K.E.; CARPENTER, J.W. (Eds.). Ferrets, rabbits and rodents clinical medicine and surgery. 2.ed. St. Louis: Saunders, 2004. p.356-369.

HESS, L. Dermatologic diseases. In: QUESENBERRY, K.E.; CARPENTER, J.W. (Eds.). Ferrets, rabbits and rodents clinical medicine and surgery. 2.ed. St. Louis: Saunders, 2004. p.194-202. 
JANÉ, D.R.; ZAVATTARO, A.L.; FLORIANO, B.P. et al. Estudo anatômico dos nervos isquiático e femoral em cadáveres felinos e lagomorfos para técnica de injeção perineural. In: CONGRESSO BRASILEIRO DE ANESTESIOLOGIA VETERINÁRIA， 13., 2018, Brasília. Anais... Brasília: CBAV, 2018. p.45. (Resumo).

LICHTENBERGER, M.; KO, J. Anesthesia and analgesia of small mammals and birds. Vet. Clin. North Am. Exot. Anim. Pract., v.10, p.293-315, 2007.

LOPEZ, A.M.; SALA-BLANCH, X.; MAGALDI, M. et al. Ultrasound-guided ankle block for forefoot surgery. Reg. Anesth. Pain Med., v.37, p.554-557, 2012.

MOSING, M.; REICH, H.; MOENS, Y. Clinical evaluation of the anaesthetic sparing effect of brachial plexus block in cats. Vet. Anaesth. Analg., v.37, p.154-161, 2010.

NAJMAN, I.E.; FERREIRA, J.Z.; ABIMUSSI, C.J.X. et al. Ultrasound-assisted periconal ocular blockade in rabbits. Vet. Anaesth. Analg., v.42, p.433-441, 2015.
PAPESCHI, C. Las enfermedades más importantes de la piel de los conejos. Culnicultura. 2018. Disponible en: http://cunicultura.com/pdf-files/2010/10/013020-Patologia-Enfermedades-piel-conejosPapeschi-CU20101015.pdf>. Accedido en: 28 mar. 2018.

SHILO, Y.; PASCOE, P.J.; CISSELL, D. et al. Ultrasound-guided nerve blocks of the pelvic limb in dogs. Vet. Anaesth. Analg., v.37, p.460-470, 2010 .

SILVA, R.M.M.; DÓREA NETO, F.A.; NUNES, N. et al. Intraocular pressure, mean arterial blood pressure and pupillary diameter in rabbits (Oryctolagus cuniculus) subjected to retrobulbar block with different anesthetic protocols. Ciênc. Anim. Bras., v.16, p.630-638, 2015.

SUNG, D.H. Locating the target nerve and injectate spread in rabbit sciatic nerve block. Reg. Anesth. Pain Med., v.29, p.194-200, 2004.

TREIN, T.A.; FLORIANO, B.P.; WAGATSUMA, J.T. et al. Effects of dexmedetomidine combined with ropivacaine on sciatic and femoral nerve blockade in dogs. Vet. Anaesth. Analg., v.44, p.144-153, 2017. 